\title{
係留アンカーの把駐力特性の検討 \\ A CONSIDERATION ON HOLDING POWER OF MOORING ANCHORS
}

\author{
前野賀彦 $1 \cdot$ 石川 元康 $2 \cdot$ 熊谷 裕児 $3 \cdot$ 村川 博 3 \\ Yoshihiko MAENO, Motoyasu ISHIKAWA, Yuji KUMAGAI and Hiroshi MURAKAWA \\ ${ }^{1}$ 正会員 農博 日本大学短期大学部 建設学科（T 274-8501 千葉県船橋市習志野台 7-24-1） \\ 2 正会員 工修 日本大学短期大学部 建設学科（同作） \\ 3 海洋工事污濁防止協会 （广 153-0043 東京都目黒区東山 3-22-1）
}

\begin{abstract}
The holding power of the mooring anchors were verified by comparing the estimation with the results by the field test. The field tests on the silty sand seabed were carried out for the holding power of two different types of anchor, the concrete block anchor and the suction anchor. The pressure distributions were measured at the bottom of the concrete block anchors and inside the suction anchor by varying the drawing angles of the anchor line, the drawing speed. The holding power of both anchors for the drawing angle of $\theta$ $=90^{\circ}$ increases with the drawing speed, and approaches to the constant value. The holding power for the drawing angle of $\theta<45^{\circ}$ approaches to the constant value independently of the drawing speed. The concrete block anchor shows a peak of the largest holding power when the drawing speed is large. The suction anchor always shows a peak of the largest holding power independently of the drawing speed. It was also confirmed that the internal pressure inside the suction anchor changes in proportion to the holding power.
\end{abstract}

Key Words : Holding power, concrete anchor, suction anchor

\section{1.はじめに}

海洋に囲まれた日本においては，その地理的特性 上, 空港等の開発に際しては沿岸域の利用がまず考 えられるところである. 近年は沿岸域での干潟・藻 場・砂浜・珊瑚礁等の環境に対する重要性が以前より 増して認識されるようになっており，埋立てや浚渫 を伴う海洋工事の可否は慎重に検討される必要があ る. 他方, 沖合・大水深海域での浮遊式構造物の展開 が埋立に代わるものとして检討されている.このよ うな海域では, 激しい波・流れの影響によって浮体へ の外力が増加するため, 浮体係留のアンカーは重量 化・大型化することが想定される.このため, 大きな 漂流力に耐えうる係留技術の開発が求められる. 海 洋工事の際に用いられる污濁防止膜, 浮防波堤, ポン ツーン等の浮遊式海洋構造物の係留は一般的には, 係留索・係留鎖によってコンクリートブロックアン カーに接続する方法が操られている. 特に, 比較的浅 い水深ではこのような方法が経済的であり, 多く用
いられている. 従来, ブロック型アンカーの把駐力の 算定に関しては, 土木学会1) や日本港湾協会2) の提 案式が採用されているが, 把駐力への影響が大きい と考えられるアンカーの引抜き角, 引抜き速度, アン カー形状, 土被り量等が考慮されていないのが現状 である. 前野等3)は浮体係留へのサクションアンカー の適用性を検討し, さらに, 污濁防止膜の各種係留ア ンカーの実測張力を用いて各種浮体係留アンカーの 応答特性を検討した ${ }^{4)}$ ，それらの一連の研究の中でサ クションの効果がサクションアンカーのみならず重 カ式のコンクリートブロックアンカーにおいても顕 著であることが認められた 5). そこで, 本研究では, 係留アンカーの把駐力についての諸特性を把握する ことを目的として，一般に海洋工事で用いられてい るコンクリートブロックアンカー, およびアンカー の大型化・重量化に対処するための係留方法として 小型軽量で把駐効果が大きいと考えられる円筒形鋼 管のサクションアンカーの 2 種類について夷海域で 把駐力試験を行い，把駐力に対する倸留索の引抜き 


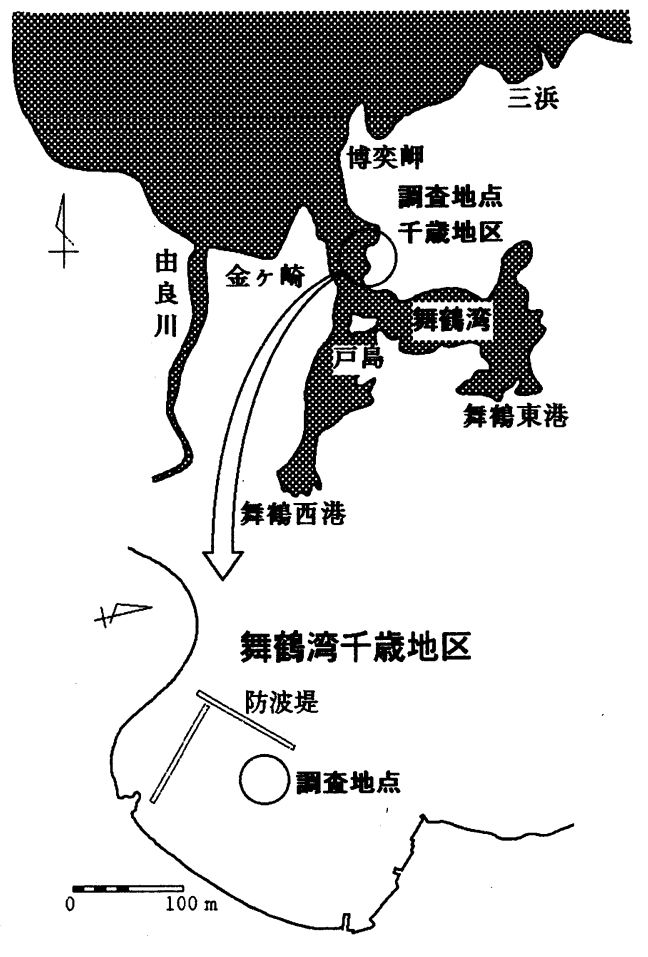

図－1 試験地点の概要

角の影響，引抜き速度の影響を検討し，さらに，コン クリートブロックアンカーの底面圧力分布特性およ びサクションアンカー内の圧力特性を検討した.

\section{2. 現地試験の概要}

現地試験は，海底地盤の調查が事前に行われてお り，波の影響が少ないと考えられる京都府舞鶴市千 歳地区（図一1）において行った. 調査日時は 1997 年 11 月 22 日〜 11 月 24 日で，当日は波浪の影響は ほとんど認められなかった. アンカーを設置した水 深は $12.2 \mathrm{~m} \sim 13.1 \mathrm{~m}$ である. 隣接する防波堤の施工 前のボーリングデータより調査地点周辺海域の海底 地盤はシルト質砂であり，表層 $1 \mathrm{~m}$ までの $\mathrm{N}$ 值は 0 〜3であることが推定される. なお, 調查地点の海底 地盤表層の底質を試料採取し，土の物理試験を行っ た結果からも海底地盤がシルト質砂であることが確 認された。現地試験で用いたアンカーは，図ー2お よび表ー 1 に示すように，一般に污濁防止膜等の浮 体構造物の係留で用いられているコンクリートブ ロックアンカー (Anchor A, Anchor B) と, 円筒 形鋼管の上部を閉じ，底面のみを開いた構造のサク ションアンカー (Anchor C) の二種類を使用した. ここで言うところのサクションアンカーとは円筒セ ル内を閉じた構造とすることにより，引抜き時にサ クションカが発生し易く, 大きな把駐力を発揮する ことが期待されるものである.図一 2 (a)〜 (c)に示す

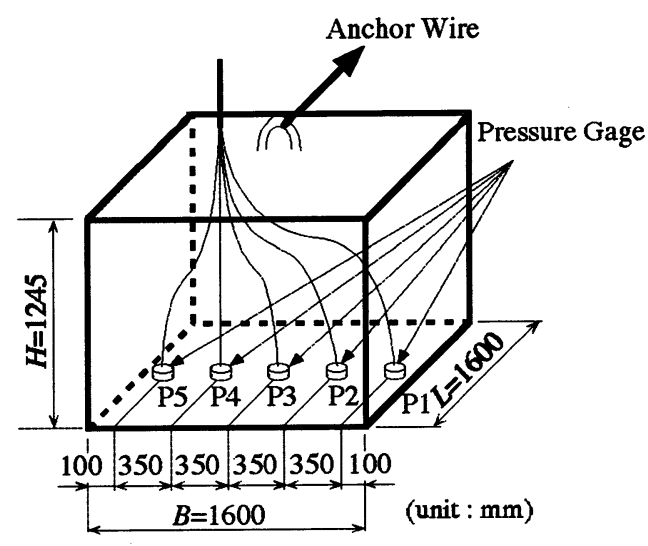

(a) Anchor $\mathrm{A}$

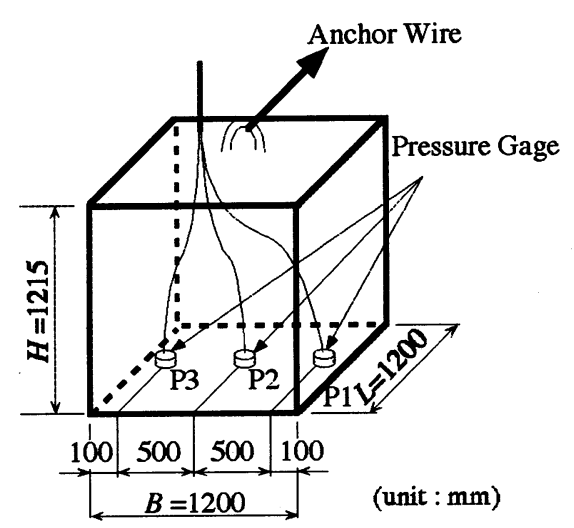

(b) Anchor B

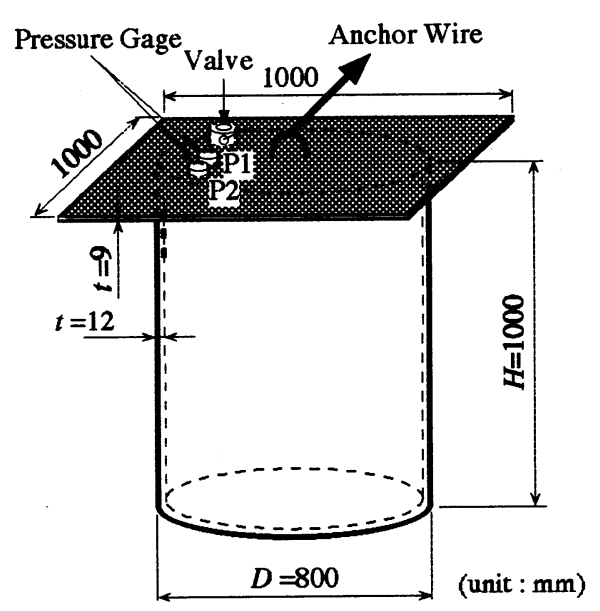

(c) Anchor C

図一2 アンカーの概略図

表ー 1 アンカーの概要

\begin{tabular}{|c|c|c|c|}
\hline & Anchor A & Anchor B & Anchor C \\
\hline 材 & Concrete & Concrete & Steel \\
\hline 偪(直径D ) B (m) & 1.600 & 1.200 & 0.800 \\
\hline 奥行 $L(\mathrm{~m})$ & 1.600 & 1.200 & - \\
\hline 高さ $H(\mathrm{~m})$ & 1.245 & 1.213 & 1.000 \\
\hline 水中重量 $W_{s}(\mathrm{kN})$ & $41.75(4.26 \mathrm{tf})$ & $24.50(2.50 \mathrm{t})$ & $2.25(0.23 \mathrm{tf})$ \\
\hline 空中重量 $W_{A}(\mathrm{kN})$ & $75.36(7.69 \mathrm{tf})$ & $43.12(4.40 \mathrm{tf})$ & $2.65(0.27 \mathrm{tf})$ \\
\hline
\end{tabular}




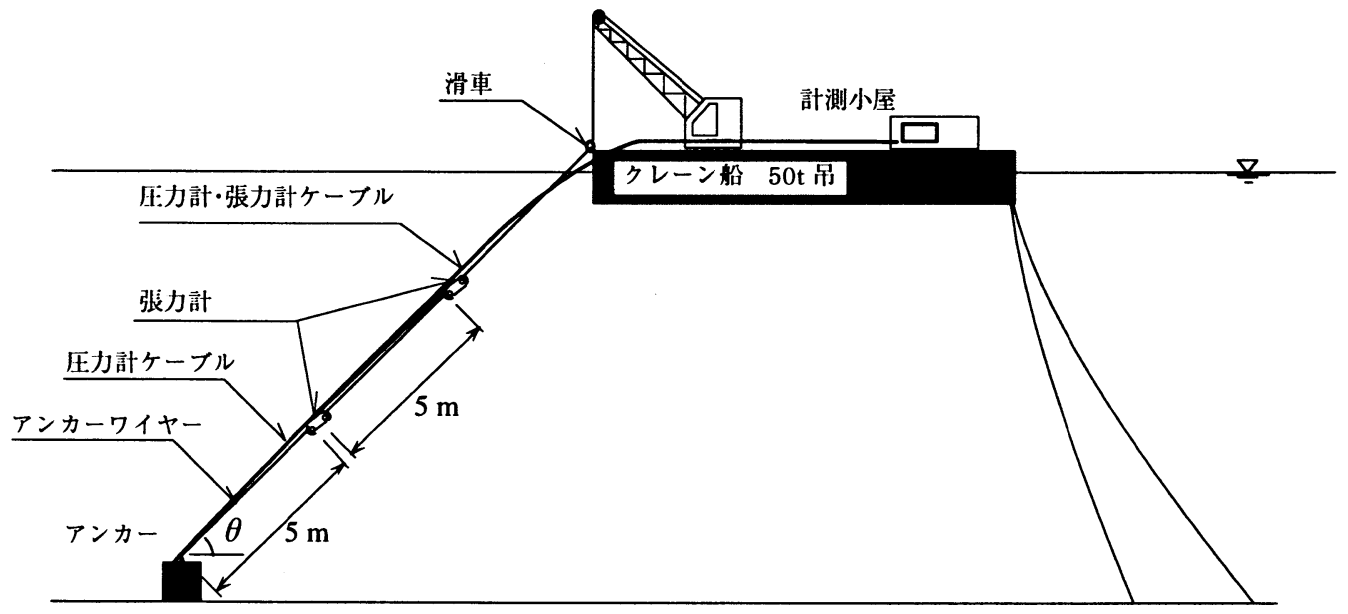

図ー3 クレーン付き台船によるアンカー把駐力測定の概略図

ようにコンクリートブロック底面の圧力分布を測定 するために, Anchor Aについてはブロック底面の 5 力所, Anchor Bについてはブロック底面の 3 力所, Anchor Cについてはアンカー内側の上端2力所に圧 力計 (共和電業, BP-5KB) を設置した. 把駐力の測 定は, 図一 3 に示すように, 係留索張力の作用方向 の測定も必要であることから係留索の途中 2 力所に シャックルで取り付けた張力傾斜計（共和電業 : BLTK-30T) により係留索張力, およびその作用方 向を測定した. アンカー把駐力の計測は, 水平面とア ンカーワイヤーとのなす角 $\theta$ が $90^{\circ} \sim 20^{\circ}$ 範囲で 測定を行った. 引き抜き速度は係留ワイヤーに目印 を付け，目視およびビデオ撮影を同時に行い，ワイ ヤーの引き上げ量と時間から引抜き速度を測定した. アンカーの土被り量は，コンクリートブロックでは 側方4面, サクションアンカーでは対角の 2 力所をア ンカーの引抜き開始前にダイバーがスケールで測定 した.

\section{3. 結果と考察}

\section{（1）引抜き速度と引抜き角度の影笠}

最大把駐力 $T_{\text {max }}$ をアンカーの水中重量 $W_{A}$ で除し た無次元把駐力と引抜き速度との関係を図ー4 (a ), (b)に示す. コンクリートブロックアンカーの場合, 図ー4(a)に示されるように引抜き角度 $\theta=90^{\circ}$ で は，引抜き速度が增加するにしたがって無次元把駐 力は增加する傾向を示すが, アンカー引抜き角度が $45^{\circ}$ 以下では引抜き速度に関わらず無次元把駐力は ほぼ一定値を示す傾向が認められる. また, 引抜き速 度が一定のもとでは $\theta=90^{\circ}$ で把駐力は最大值を示

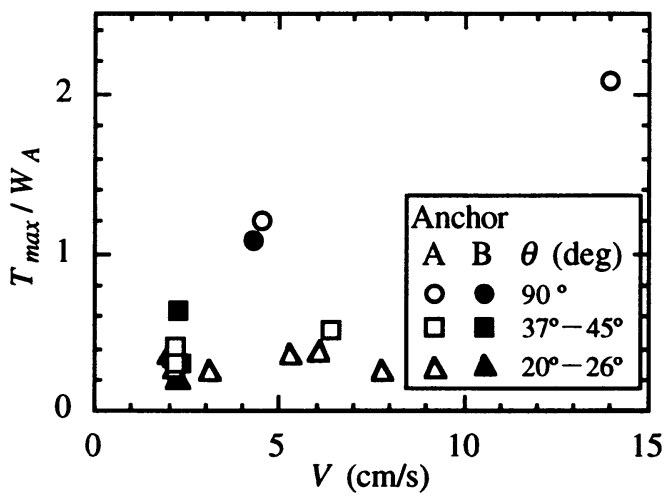

(a) Anchor A, Anchor B

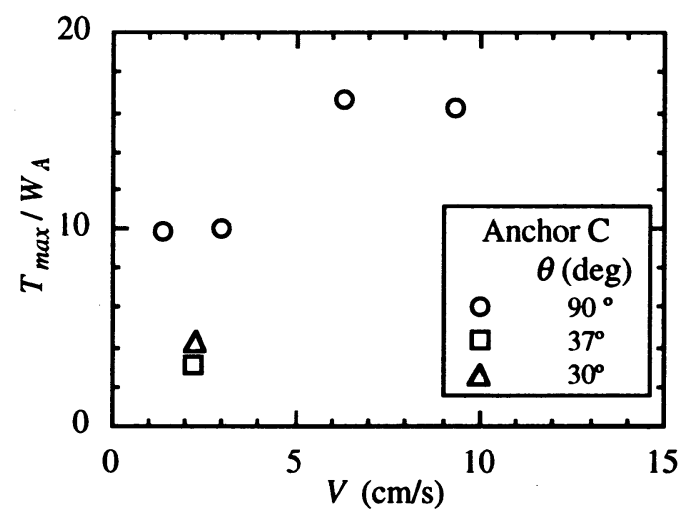

(b) Anchor C

図ー4 無次元把駐力と引抜き速度との関係

し, $\theta$ の減少に伴って把駐力は減少するが, $\theta=45^{\circ}$ 以下では把駐力の変化は顕著でなくほぼ同じ值と なっている.さらに, $\theta=90^{\circ}$ の場合を除いて把駐力 はアンカー水中重量よりも小さい值を示している. 斜めに引抜き力が作用した場合は, アンカーに転倒 モーメントが大きく働くことによって把駐力はアン カー水中重量以下の值を示すものと考えられる。 サ クションアンカーの場合, 図一 4 ( b ) に示されるよ 

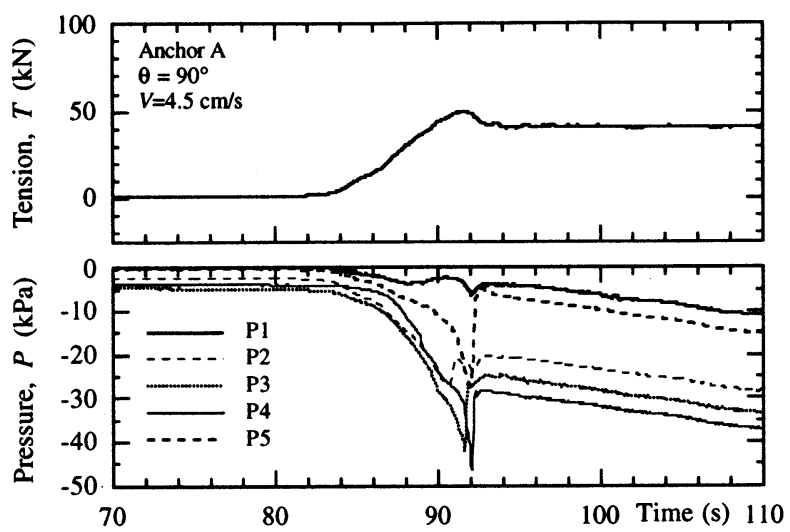

(a) Anchor A $(V=4.5 \mathrm{~cm} / \mathrm{s})$
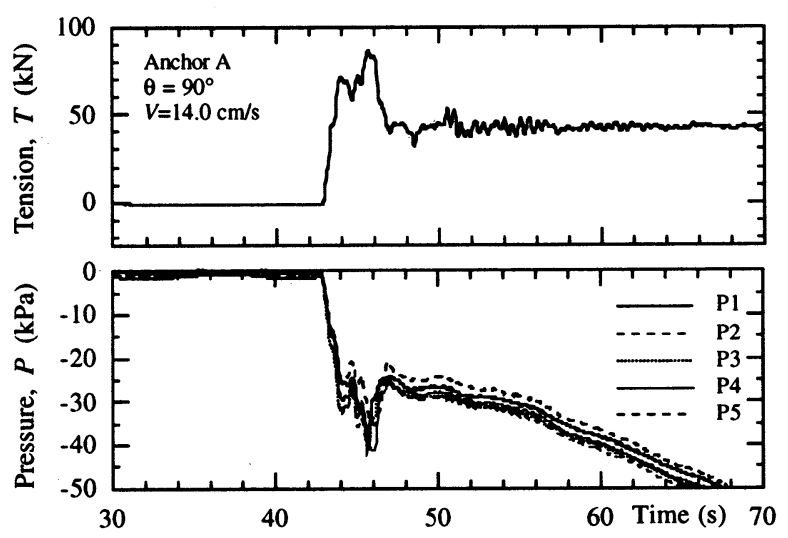

(b) Anchor A $(V=14.0 \mathrm{~cm} / \mathrm{s})$

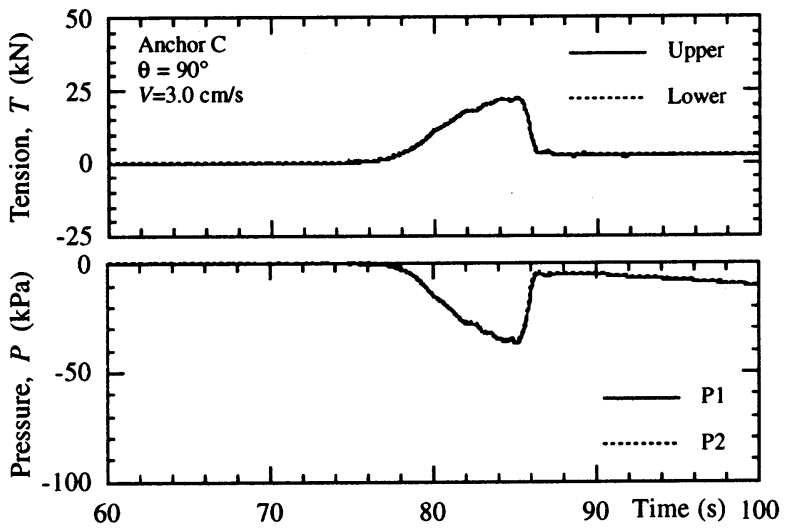

(c) Anchor C $(V=3.0 \mathrm{~cm} / \mathrm{s})$

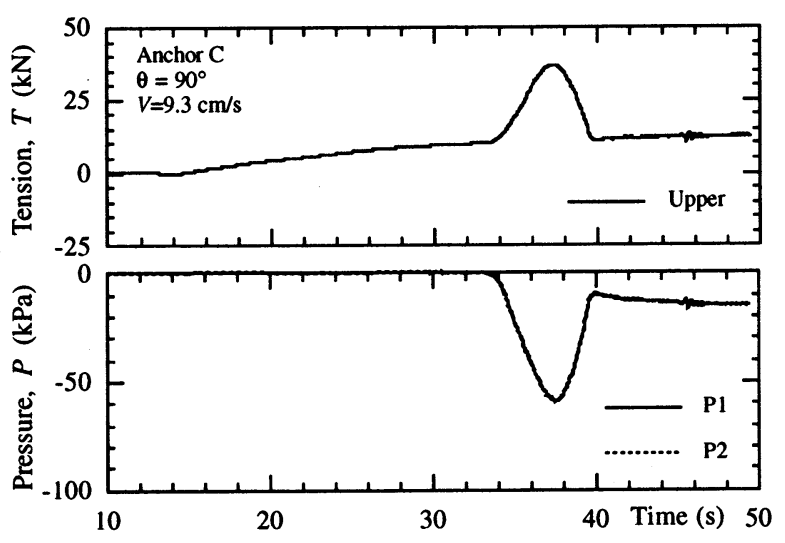

(d) Anchor C $(V=9.3 \mathrm{~cm} / \mathrm{s})$

図一 5 把駐力と底面圧力の時系列 $\left(\theta=90^{\circ}\right)$

うに, $\theta=90^{\circ}$ ではコンクリートブロックアンカーの 場合と同様に引抜き速度が増加するにしたがって無 次元把駐力は増加する傾向が見られ, 引抜き速度が 一定のもとではコンクリートブロックアンカーの場 合と同様に $\theta=90^{\circ}$ で最大を示し, $\theta=45^{\circ}$ 以下で は把駐力はほぼ同じ値となっている.

以上のように, 引抜き速度と引抜き角度の変化に 対する把駐力の傾向は, コンクリートブロックと円 筒形鋼管共に同様の傾向を示すことが確かめられた.

\section{（２）アンカー底面圧カの特性}

アンカー引抜き角度 $\theta=90^{\circ}$ の場合における把駐 カ $T$ およびアンカー底面圧力 $P$ の時系列変化の一例 を図一 5(a)〜(d)に示す. なお, 圧力の值はアン カーが着底したときの值を初期値零として示してい る. Anchor Bについては圧力計の故障のためにデー 夕を得ることができなかった.

Anchor Aの場合, 図一 5(a), ( b )に示されるよ うに, 把駐力の時系列波形は引抜き速度によって異 なり, 引抜き速度が大きい場合には顕著な最大把駐 カのピークが認められる. また, コンクリートブロッ ク底面の圧力分布形状は, 引抜き速度が小さい場合,
アンカー端部から中央部に向かって圧力 (負圧) が増 加する傾向を示し, 引抜き速度が大きい場合, アン カー端部から中央部までほぼ一様な圧力分布を示す ことが分かる.このことから, 引抜き速度が大きい場 合にはアンカー底面のサクションカ（負圧による抵 抗力）が大きくなることによって把駐力が大きい値 を示すものと考えられる.

次に, Anchor Cの場合, 図一 5(c), (d)に示さ れるように, 引抜き速度に関わらず同様の把駐力の 時系列波形を示し, 把駐力に対応してアンカー内部 の圧力が変化している. また, 引抜き速度が大きいほ ど, 引き抜き抵抗力, アンカー内部の圧力（負圧）は 共に大きくなっていることが認められる.

アンカー引抜き角度 $\theta<90^{\circ}$ の場合における $T$, $P$ および引抜き角度の時系列変化の一例を図一 6 ( a ), ( b ) に示す. なお, アンカーの引抜き方向に圧力 計 P1 が設置してある．これによると, コンクリート ブロックの場合, $\theta<90^{\circ}$ の場合とは異なり, ブロッ ク底面の圧力分布は引張りによってブロックが回転 するため, 底質を押す正の圧力がP1〜P3にかけて作 用し, P4, P5 はその逆となっている. T が最大值を 示した後にアンカーは転倒することによって, 底面 

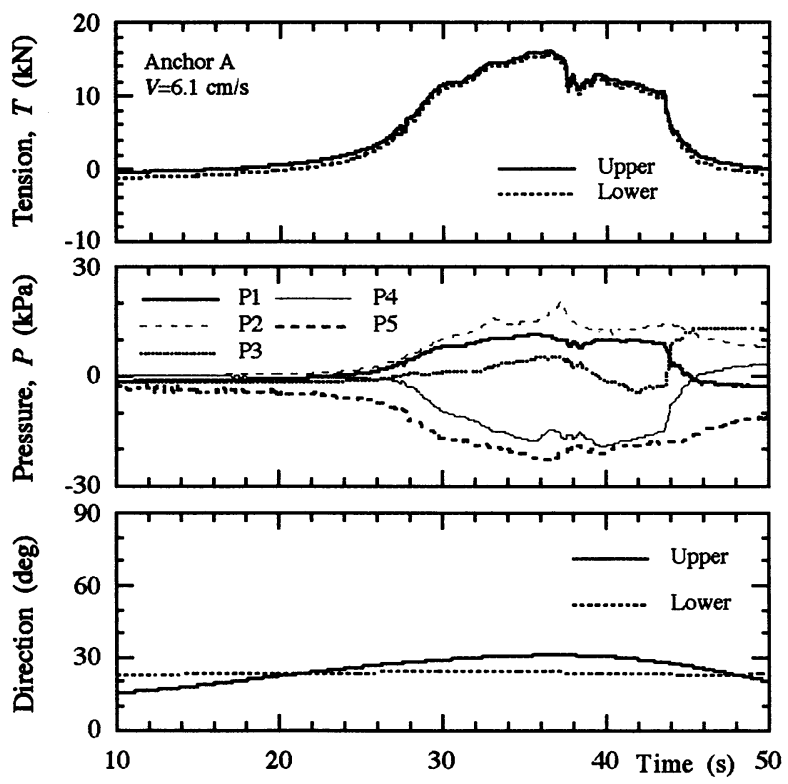

(a) Anchor A $(V=6.1 \mathrm{~cm} / \mathrm{s})$
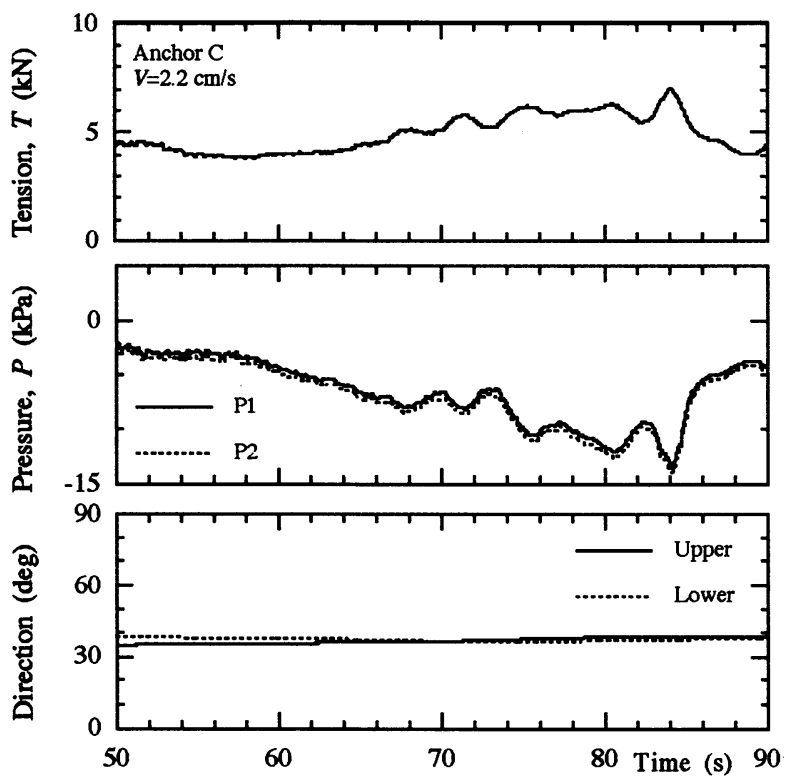

(b) Anchor C $(V=2.2 \mathrm{~cm} / \mathrm{s})$

図一 6 把駐力之底面圧力の時系列 $\left(\theta<45^{\circ}\right)$

は底質から抜け上がる．この時， $T$ は急激に減少し， アンカーブロックの転倒軸付近である P1，P2 の底面 圧力は減少し, 逆にP3〜P5は底質からアンカーが抜 け上がることで圧力が増加する.サクションアンカー の場合, $\theta<90^{\circ}$ の場合とは異なり, アンカーが回 転することによって内部圧力が抜けてしまい,顕著な サクションカのピークは認められない.

\section{（３）サクションアンカーの把駐カの試算}

$\theta=90^{\circ}$ の場合におけるサクションアンカーの把駐 力は, 底面圧力, 土被り部の周面摩擦抵抗力, アン カーの水中重量, アンカー内部の土の水中重量の和に

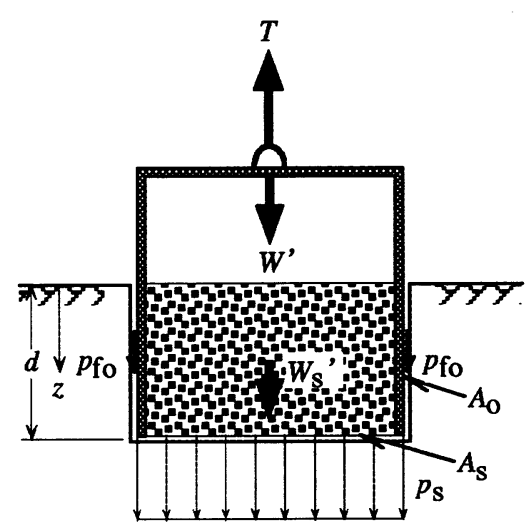

図ー 7 サクションアンカーのモデル

よって与えられるものと考えられる.ここでは, 実験 結果に基づき，サクションアンカーの垂直方向の最 大把駐力発生時における把駐力を図一 7 のように簡 単化し，算出を試みる。

最大把駐力発生時にはアンカー内部の土塊がアン カ一本体と一体となって抜け上がり，アンカー内部 と底面の圧力は等しいものと考える. 現地実験での 観測状況から，サクションアンカー内部の底質は抜 け落ちることなくサクションカによって持ち上がっ ていると見なせる．また，底面圧力は一様に分布し， 鋼管の厚さを無視すると， $T$ は次式で示される.

$$
T=\int p_{s} d A_{s}+\int p_{f o} d A_{o}+W^{\prime}+W_{s}^{\prime}
$$

ここに, $A_{o}$ は土被り部のアンカー外周面の表面積, $A_{s}$ はアンカー断面積, $p_{s}$ はアンカー底面に作用するサク ション (負の圧力), $p_{f o}$ はアンカー外周面摩擦力, $W$ はアンカー水中重量, $W_{s}^{\prime}$ はアンカー内部の土の水中 重量である.

周面摩擦力は, 山崎ら 6) による砂地盤におけるサ クション基礎の引抜き抵抗力の算出に基づき, ク一 ロンの破壊規準と土圧你数用いて表し, 有効鉛直応 力をアンカ一底面圧力が地盤表面で 0 となる直線分 布すると仮定すると，次式が得られる.

$$
p_{f o}=c+K\left(\gamma^{\prime} z+p_{s} z / d\right) \tan \delta
$$

ここに, $c$ は粘着力, $K$ は土圧係数, $\delta$ はアンカーと 土之の間の摩擦角, $\gamma$ 'は土の有効単位体積重量, $z$ は アンカー外部の地盤表面からの深さである.

以上より，式(2)を式(1)へ代入すると次式が得られ る.

$$
\begin{aligned}
& T=\frac{\pi D^{2}}{4} p_{s}+\pi D c d+\pi D K\left(\gamma^{\prime}+\frac{p_{s}}{d}\right) \frac{d^{2}}{2} \tan \delta \\
& +W^{\prime}+\frac{\pi D^{2}}{4} d \gamma^{\prime}
\end{aligned}
$$




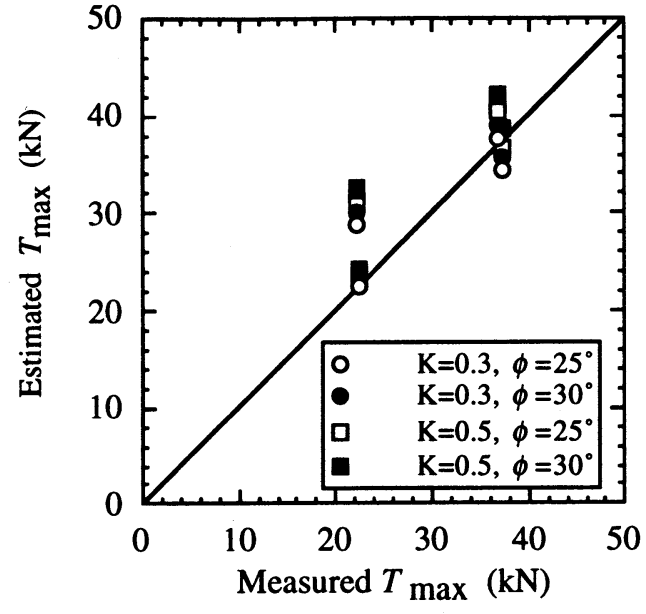

図ー8 把駐力の計算値と実験值の比較

ここに, $D$ はサクションアンカーの直径, $d$ はアン カー埋設深さである.

式(3)中に現地試験結果による最大内部圧力 $p_{s}$ を与 え, 他の入力するパラメータを次のように与えて把 駐力 $T$ の算出を行い，その結果を図一 8 に示す．な お， $\phi$ (せん断抵抗角）と $K$ は把駐力に対する感度を 見るためにそれぞれ 2 種類の值を与えた.

$$
\begin{aligned}
W^{\prime} & =2.25 \mathrm{kN} \\
c & =0 \\
\gamma^{\prime} & =0.7 \mathrm{tf} / \mathrm{m}^{3} \quad\left(6.86 \mathrm{kN} / \mathrm{m}^{3}\right) \\
\delta & =2 / 3 \phi \\
\phi & =25^{\circ}, 30^{\circ} \\
K & =0.3,0.5
\end{aligned}
$$

図一 8 に示されるように，全体的に計算值が大き い值を示しているが, $\phi=25^{\circ}, K=0.3$ のとき，実 験値と計算值は良い対応を示している．実験におい ては, 設計上安全側となるよう考慮して, アンカーは 海底面に設置後すみやかに把駐力の測定を行ったた めに, 周辺の地盤は乱され, 流動化しているため, 周 面摩擦抵抗力の計算値は実際よりも大きく見積もっ ているものと考えられる.

\section{4.おわりに}

本研究により得られた結論を以下に示す.

1) 引抜き速度に対する把駐力の発達特性として, 引 抜き角度が $\theta=90^{\circ}$ の場合, コンクリートブロッ クアンカー, サクションアンカー共に引抜き速度
の増加に伴って把駐力は増加し，ある一定値に漸 近する傾向を示す. また, 引抜き角度が $\theta=45^{\circ}$ 以下の場合, コンクリートブロックアンカー, サ クションアンカー共に引抜き速度に関わらず，把 駐力はある一定值に漸近する傾向を示す。

2 ) 引抜き角度に対する把駐力の発達特性として, 引 抜き速度が一定のもとでは， $\theta=90^{\circ}$ で把駐力は 最大值を示し, $\theta$ の減少に伴って把駐力は隇少す るが, $\theta=45^{\circ}$ 以下ではその傾向は顕著ではない. このことは, 斜めに引抜き力が作用した場合には, 転倒モーメントの影響が大きいことによるものと 考えられる.

3 ) 引抜き角度が $\theta=90^{\circ}$ の場合におけるコンクリー トブロックアンカーの底面の圧力分布特性として は，引抜き速度が大きい場合には顕著な最大把駐 カのピークが認められ，この時アンカーの底面全 体に渡ってサクションカが作用していることが確 かめられた。 また，同じ条件でサクションアン カーは, 引抜き速度に関わらず常に顕著な最大把 駐力のピークが認められ, この時アンカー内部の 圧力は把駐力に対応して変化することが確かめら れた。

4) サクションアンカーの把駐力の時系列波形は, 引 抜き速度に関わらず同様の波形を示し，アンカー 内部の圧力は把駐力に対応して変化することが確 かめられた。

\section{参考文献}

1）土木学会 : 海洋鋼構造物設計指針（案), 1973.

2）日本港湾協会 : 港湾の施設の技術上の基準・同解説, 1989.

3)前野賀彦・高谷富也・平石哲也・高山知司 : 浮体係留へ のサクションアンカーの適用について, 海岸工学論文集, 第 40 巻, pp.906-910, 1993.

4)前野賀彦・高谷富也・西野好生・安井章雄 : 污濁防止膜 の各種係留アンカーの実測張力による変位応答特性, 海 岸工学論文集, 第 42 巻, No.2, pp.971-975, 1995.

5)前野賀彦・高谷富也・村川 博 - 川本博文 : 污濁防止膜 の重力式係留アンカーの応答特性, 海洋開発論文集, Vol.11, pp.217-222, 1995.

6）山崎浩之・善 功企・舘下 徹 : サクション基礎の引き 抜き抵抗のメカニズムに関する研究, 第39回土質工学シ ンポジウム, pp.73-80, 1994.

（1999.4.19 受付） 